\title{
8. TRADYCYJNY DORADCA FINANSOWY 2.0 A ROBODORADCA
}

\author{
(iD) Katarzyna Perez \\ Uniwersytet Ekonomiczny w Poznaniu \\ katarzyna.perez@ue.poznan.pl \\ https://doi.org/10.18559/978-83-8211-083-8/8
}

\section{Financial advisor 2.0 and robo-advisor}

\begin{abstract}
The aim of this chapter is to answer the question whether the financial services market is able to permanently integrate the appropriate technology and dayto-day work of a traditional financial advisor, so that it is potentially as effective and automated as robots, and even offers a higher quality of services. If so, can the price of such advice be low enough to make it affordable to the average retail investor? The chapter presents the history and characteristics of an advisor 2.0 and a robo-advisor. Then, using the SWOT analysis, the strengths and weaknesses, as well as opportunities and threats for both types of services are shown. We base the analysis on the literature on financial advisory, which in the last decade has grown substantially in both variants due to the dynamic development of these services. The chapter ends with conclusions about the answer to the questions raised at front.
\end{abstract}

Keywords: financial advisor 2.0, robo-advisor, investment portfolio management, financial services.

\subsection{Wstęp}

Tradycyjny doradca finansowy to osoba indywidualna, która oferuje profesjonalne doradztwo w sprawach finansowych innym osobom indywidualnym lub instytucjonalnym w zamian za wynagrodzenie. Doradca taki powinien posiadać odpowiednie kwalifikacje zawodowe i wypełniać obowiązki, które są formalnie uregulowane. Powinien umieć rozumieć cele i oczekiwania finansowe, a nawet nastroje swoich klientów, ponieważ to oni tworzą popyt na jego usługi, a także są ich finalnymi odbiorcami. Usługi te nie są łatwe do wyceny, jednak mają wartość, za którą klienci chcą zapłacić (Cruciani, 2017). Wartość ta - a jednocześnie relacja klient-doradca - jest sumą trzech elementów: wyników inwestycyjnych, zaangażowania oraz zaufania. To dzięki nim klienci mają otrzymać profesjonalne wsparcie w podejmowaniu decyzji finansowych na rynku finansowym, który bezsprzecznie wiąże się z niepewnością i ryzykiem. Decyzje te, dzięki wsparciu doradcy finansowego, mają być lepsze i efektywniejsze. 
Badania naukowe dowodzą, że tradycyjne doradztwo finansowe jest korzystne dla inwestorów indywidualnych, pozwala im bowiem na realizowanie bardziej opłacalnych strategii inwestycyjnych. Racjonalne zachowanie doradców wywołuje u inwestorów większy spokój i większe zaufanie, co prowadzi do zmniejszenia awersji do ryzyka (Foerster, Linnainmaa, Melzer i Previtero, 2017; Gennaioli, Shleifer i Vishny, 2015). Z drugiej strony podnosi się, że w relacji klient-doradca występują różne konflikty interesów. Doradcy popełniają te same błędy na własnych rachunkach inwestycyjnych, co na rachunkach swoich klientów, a tym samym przekazują klientom własne uprzedzenia. Dokonują częstego obrotu instrumentami finansowymi, ,gonią" za stopami zwrotu, preferują drogie i aktywnie zarządzane fundusze i nie dywersyfikują portfela inwestycyjnego (Linnainmaa, Melzer i Previtero, 2021). Zatem ich nieracjonalne zachowanie jest dla inwestorów nie tylko nieefektywne, ale i drogie (Hackethal, Haliassos i Jappelli, 2012). Powyższe wywołuje pytanie, czy tradycyjni doradcy finansowi mogą tworzyć wartość dla osób, których środkami zarządzają. W obliczu czwartej rewolucji gospodarczej tworzącej tzw. gospodarkę 4.0, opartej na cyfryzacji różnych usług wydaje się, że tak. Dziś bowiem coraz częściej mamy do czynienia z tradycyjnym doradcą finansowym 2.0 (financial advisor 2.0). Doradca taki tworzy tę wartość i działa bardziej racjonalnie, co służy zwiększeniu efektywności decyzji podejmowanych przez jego klientów, wykorzystując najnowsze narzędzia technologiczne. Narzędzia te opierają się na automatyzacji procesów zarządzania i optymalizacji portfela inwestycyjnego i są najczęściej wykorzystywane w ramach robodoradztwa.

Robodoradca (robo advisor lub digital advisor) stał się alternatywą dla tradycyjnego doradcy finansowego na kanwie globalnego kryzysu finansowego z lat 2007-2009 oraz dynamicznego rozwoju gospodarki 4.0. Robodoradca to robot występujący w postaci platformy cyfrowej, który udziela inwestorom porad finansowych w sposób zautomatyzowany. W zależności od stopnia zaawansowania robodoradcy gromadzą i wykorzystują szczegółowe informacje dotyczące danej osoby w celu udzielenia porady finansowej lub (i) tworzenia planów finansowych dostosowanych do potrzeb i możliwości tej osoby. Robodoradca nie jest człowiekiem, nie odczuwa emocji, zatem jego praca jest bardziej racjonalna, a osiągane przez jego klientów wyniki bardziej efektywne. Z tego względu robodoradca jest alternatywą dla tradycyjnego doradcy finansowego i sposobem na pokonanie jego ograniczeń (D’Acunto i Rossi, 2020).

Celem tego rozdziału jest charakterystyka i porównanie robodoradcy i tradycyjnego doradcy finansowego, którego dziś nazywamy doradcą 2.0. Pytaniem, które przyświeca realizacji tego celu, jest to, czy rynek usług finansowych jest w stanie trwale zintegrować odpowiednią technologię i codzienną pracę tradycyjnego doradcy finansowego, tak aby potencjalnie był on równie efektywny i zautomatyzowany jak roboty, a nawet oferował większą jakość usług. Jeśli tak, to powstaje 
kolejne pytanie, czy cena takiego doradztwa może być na tyle niska, aby było ono dostępne dla przeciętnego inwestora detalicznego. W dalszej części rozdziału zaprezentowano genezę i charakterystykę doradcy 2.0 oraz robodoradcy. Następnie za pomocą modelu SWOT ukazano mocne i słabe strony oraz szanse i zagrożenia obu rodzaju usług. Przy tym wykorzystano literaturę na temat doradztwa finansowego, która w ostatniej dekadzie, ze względu na dynamiczny rozwój tej usługi w obu wariantach, dość znacznie się wzbogaciła. Rozdział kończy podsumowanie, w którym zaproponowano odpowiedź na zadane wyżej pytanie.

\subsection{Geneza i charakterystyka tradycyjnego doradcy finansowego 2.0}

Doradztwo finansowe w tradycyjnej formie zostało zapoczątkowane w latach 50. XX wieku w USA i przez około trzy dekady było dostępne jedynie dla ultrabogatych inwestorów indywidualnych (ultra high net worth individuals, ultra HNWI), mających aktywa o wartości wyższej niż $30 \mathrm{mln}$ USD, najczęściej członków bogatych arystokratycznych lub kapitalistycznych rodzin. W tamtym czasie doradcy byli pracownikami domów maklerskich, sprzedawcami papierów wartościowych rekomendującymi klientom ich kupno lub sprzedaż na dynamicznie rozwijających się giełdach papierów wartościowych.

Zapoczątkowane w latach 70. XX wieku i kontynuowane w latach 80 . XX wie$\mathrm{ku}$ przeobrażenia związane $\mathrm{z}$ umiędzynarodowieniem i liberalizacją rynków kapitałowych, otwarciem się gospodarek i rynków rozwijających się, upowszechnieniem się oszczędzania na emeryturę i wreszcie globalizacją, której towarzyszył postęp technologiczny i cywilizacyjny, spowodowały z jednej strony bogacenie się społeczeństw, a z drugiej znaczne poszerzenie katalogu możliwości inwestycyjnych. Wraz z postępującym wzrostem złożoności rynku finansowego wzrosło zapotrzebowanie na doradztwo finansowe (Inderst i Ottaviani, 2012). Stało się ono popularne w latach 90 . XX wieku, kiedy zaczęło obejmować kolejne grupy inwestorów: bardzo bogatych (very HNWI, z aktywami od 5 do 30 mln USD), bogatych (HNWI, mających aktywa inwestycyjne w wysokości od 1 do $5 \mathrm{mln}$ USD), jak również zamożnych (affluent, z aktywami wynoszącymi od 0,25-0,5 do 1 mln USD). W latach 80. XX wieku klientów tych obsługiwali „konsultanci finansowi” (financial consultant), a w latach 90. XX wieku „doradcy finansowi” (financial advisor), na których większość głównych firm maklerskich przemianowała dotychczasowych konsultantów. Doradca miał zatrzeć stary wizerunek sprzedawcy nastawionego na dokonywanie transakcji i pobieranie za to dla domu maklerskiego prowizji i zastąpić go dobrze wyszkolonym profesjonalistą w dziedzinie finansów, który oferował klientom cenne porady inwestycyjne. Wydawało się to oczywistą ewolucją, biorąc pod uwagę, że rola doradcza była kluczowym elementem wizerunku „konsultanta” (Kolakowski, 2019). 
Rola doradcy inwestycyjnego w latach 90 . XX wieku i na przełomie wieków stała się dla instytucji finansowych i ich klientów coraz bardziej znacząca, na co wpływ miało kilka czynników. Po pierwsze, w związku z upowszechnieniem się oszczędzania na emeryturę i na inne cele inwestorzy indywidualni coraz częściej rezygnowali z bezpośrednich inwestycji na giełdzie papierów wartościowych na rzecz inwestycji pośrednich w tytuły uczestnictwa funduszy emerytalnych i funduszy inwestycyjnych. To fundusze - jako inwestor instytucjonalny - zaczęły wypierać inwestorów indywidualnych ze struktury inwestorów na giełdach papierów wartościowych. Po drugie, w tym czasie katalog instrumentów finansowych poszerzył się na tyle, że zaczęto je dzielić na instrumenty/inwestycje tradycyjne (na przykład akcje, obligacje czy właśnie tytuły uczestnictwa funduszy inwestycyjnych, w tym ETF) oraz na instrumenty/inwestycje alternatywne (na przykład fundusze hedge, fundusze venture capital/private equity, fundusze nieruchomości czy fundusze towarowe (commodities)). W związku z tym poszerzył się też zakres obowiązków doradców finansowych - z maklerów sprzedających akcje ewoluowali oni do doradców wealth management $\mathrm{w}$ zakresie zarządzania tradycyjnymi i alternatywnymi aktywami finansowymi i niefinansowymi osób majętnych.

Hossa na rynku kapitałowym z nowego milenium trwająca do globalnego kryzysu finansowego z 2007-2009 roku, a także kolejne lata ożywienia postkryzysowego spowodowały, że grono oszczędzających w funduszach inwestycyjnych poszerzało się systematycznie o kolejnych klientów detalicznych z różnych gospodarek i grup społecznych. Nierzadko dołączały się osoby cechujące się niską wartością środków do inwestowania i brakiem podstawowej wiedzy finansowej (Bianchi, 2018; Lusardi, Michaud i Mitchell, 2017; Lusardi i Mitchell, 2014). Popełniają one przy tym wiele błędów psychologicznych (Beshears, Choi, Laibson i Madrian, 2018), które mają konsekwencje zarówno w skali mikro - obniżają bowiem ich dobrobyt (Campbell, 2006; Campbell, Madrian i Tufano. 2011), jak i w skali makro - zwiększają nieefektywność rynków finansowych czy nierówność majątkową społeczeństw (Bach, Calvet i Sodini, 2020; Fagereng, Guiso, Malacrino i Pistaferri, 2020). Aby uniknąć tych błędów, osoby o niewystarczającym poziomie znajomości finansów są bardziej skłonne zasięgnąć porady finansowej (Karabulut, 2012). Stąd porady finansowe zaczęły przyciągać coraz więcej uwagi. Koszt osobistego profesjonalnego doradztwa finansowego jest jednak wysoki, dlatego, aby doradzać mniej zamożnym klientom, największe tradycyjne firmy zarządzające majątkiem zaczęły oferować usługi cyfrowe. W 2010 roku Bank of America ${ }^{1}$ uruchomił Merrill Edge ${ }^{\circledR}$. W 2013 roku Australia and New Zealand Banking Group Limited (ANZ) zastosowała sztuczną inteligencję (artificial intelligence, AI) z wykorzystaniem IBM Watson do zrozumienia zachowania klienta. W 2015 roku BlackRock nabył cyfrową platformę doradztwa finansowego FutureAdvisor,

\footnotetext{
${ }^{1}$ Wówczas Bank of America Merrill Lynch.
} 
aby usprawnić proces przekazywania informacji o inwestycjach. W 2017 roku te i inne instytucje finansowe, jak Charles Schwab i Vanguard, ogłosiły dokonanie znacznych inwestycji $\mathrm{w}$ technologię, aby zautomatyzować ręczne procesy doradztwa finansowego mające na celu redukcję kosztów doradztwa finansowego i przyrostu jego efektywności. W ten sposób narodził się doradca finansowy 2.0.

Tradycyjny doradca finansowy 2.0 to osoba indywidualna, która w zamian za wynagrodzenie oferuje profesjonalne doradztwo finansowe, w ramach którego wykorzystuje technologię i narzędzia cyfrowe do promocji swoich usług i kontaktu z klientem, oceny i optymalizowania procesów inwestycyjnych, a także opracowywania i wdrażania strategii inwestycyjnych. Podobnie jak w przypadku pierwotnego tradycyjnego doradcy finansowego wartość doradcy 2.0 jest wypadkową osiągniętego wyniku inwestycyjnego, zaangażowania oraz zaufania. Fundamentem relacji doradca-klient nadal pozostaje osobisty kontakt, jednak może być on nawiązywany alternatywnymi kanałami (na przykład przez media społecznościowe czy komunikatory online) i jest wspomagany narzędziami cyfrowymi pozwalającymi na dostarczanie efektywnych kosztowo i wynikowo rozwiązań.

Według specjalistów EY doradca 2.0 jest etapem ewolucji świadczenia usług zarządzania majątkiem (EY Global). Doradca 2.0 łączy aspekt ludzki z automatyzacją tych usług, zatem jest to tzw. rozwiązanie hybrydowe (Perez, 2019). Istnieje ono jako trzeci kanał doradztwa finansowego, obok kanału czysto tradycyjnego (przeznaczonego dla tradycjonalistów, którzy cenią sobie osobisty kontakt i wsparcie doradców finansowych - ludzi), oraz kanału robodoradztwa opartego na robotach w pełni automatyzujących procesy przygotowania i podejmowania decyzji inwestycyjnych, który jest preferowany na przykład przez millenialsów. W miarę rozwoju nowych technologii doradca 2.0 będzie mieć coraz większe możliwości zwiększenia wydajności i efektywności swojej pracy. EY prognozuje, że do 2025 roku rynek robodoradców wyniesie około 1,6\% zainwestowanego majątku na świecie, pozostawiając resztę jako wielką potencjalną szansę dla doradców 2.0. Potencjał ten został już dostrzeżony przez Betterment - jedną z największych niezależnych firm robodoradczych na świecie. Już w 2017 roku przedstawiciele firmy zapowiedzieli, że przyjmą model hybrydowy, który pozwoli ich klientom posiadającym co najmniej 100 tys. USD otrzymać poradę od doradcy człowieka (EY Global). Dodatkowo na platformie „Betterment 4 Advisors” firma ta oferuje narzędzia robodoradztwa dla tradycyjnych doradców finansowych (zob. www.bettermentforadvisors.com).

\subsection{Geneza i charakterystyka robodoradcy}

Geneza robodoradców sięga lat 70. XX wieku, kiedy to amerykańskim inwestorom detalicznym zaoferowano usługi „tanich brokerów” (discount brokers), tańszych 
niż tradycyjni doradcy, ponieważ nieświadczących usług doradczych, a jedynie wykonujących zlecenia kupna/sprzedaży papierów wartościowych za niską opłatę wpierw za pomocą systemów offline ${ }^{2}$, a potem online ${ }^{3}$. W połowie lat 80 . XX wieku zaoferowano zarówno inwestorom bogatym, jak i detalicznym dostęp do internetowych platform obrotu papierami wartościowymi z wbudowaną opcją pełnego i niekosztownego doradztwa inwestycyjnego ${ }^{4}$, Niecałe dwie dekady później nastała zaś era handlu algorytmicznego, która - wraz z upowszechnieniem się szybkiego dostępu do internetu w komputerach, smartfonach czy tabletach - spowodowała zmniejszanie się asymetrii informacji i obniżanie kosztów transakcyjnych (Jung, Glaser i Köpplin, 2019). Dynamiczny wzrost popularności korzystania z narzędzi cyfrowych wywołał ważną zmianę w zachowaniu osób indywidualnych, które obecnie coraz częściej komunikują się ze światem przez media społecznościowe, a nie osobiście, i nierzadko tym właśnie kanałem poszukują usług finansowych, pomijając tradycyjnych pośredników finansowych (Sironi, 2016). Zachowanie to stało się motywacją, ale i wymogiem, by zaoferować inwestorom indywidualnym opartej na technologii cyfrowej usługi robodoradztwa. Jako że nie wymaga ona bezpośredniego kontaktu z człowiekiem, ma być znacznie tańsza od tradycyjnego doradztwa (ma być wręcz bezkosztowe), w związku z czym dostępna nawet dla inwestorów z niską wartością aktywów finansowych (Jung, Dorner, Weinhardt, $\mathrm{i}$ in., 2018).

Najogólniej rzecz ujmując, robodoradca to urządzenie zastępujące tradycyjnego doradcę, które udziela porad dotyczących decyzji finansowych, najczęściej w obszarze alokacji kapitału (Perez, 2019). Urządzeniem tym jest platforma cyfrowa, która wykorzystuje technologie informacyjne do przeprowadzania klientów przez zautomatyzowany proces doradztwa finansowego i zarządzania inwestycjami bez interwencji człowieka, przy użyciu algorytmów i modeli alokacyjnych, które jak sprawdzili Beketov, Lehmann i Wittke (2018) - są w większości przypadków oparte na nowoczesnej teorii portfela inwestycyjnego H. Markowitza (1952) (Jung, Dorner, Glaser i Morana, 2018). Usługi robodoradztwa powstały w odpowiedzi na potrzeby uzyskania prostej i niedrogiej, ale jednocześnie zindywidualizowanej porady inwestycyjnej przez drobnych inwestorów i są do tych potrzeb dostosowane (Chiu, 2016).

${ }^{2}$ Brokerstwo rozpowszechniło się szybko dzięki powstaniu Instinet, czyli platformy komunikacji elektronicznej off-line będącej konkurencją do New York Stock Exchange, którą wprowadzono w USA w 1967 roku (Kunz i Martin, 2015).

${ }^{3} 8$ lutego 1971 r. powstał National Association of Securities Dealers Automated Quotations (NASDAQ), która stała się pierwszym na świecie rynkiem elektronicznego obrotu akcjami (Library of Congress).

${ }^{4} \mathrm{Z}$ platform tych dziś korzysta raczej ograniczona liczba inwestorów indywidualnych zainteresowanych i specjalizujących się w handlu papierami wartościowymi (por. Schwinn i Teo, 2018). 
Robodoradcy stosują zautomatyzowane procedury: począwszy od stosunkowo prostych algorytmów, które wykorzystują ograniczone informacje o kliencie, skończywszy na złożonych systemach zbudowanych na big data. Na podstawie tych informacji wydają rekomendacje dotyczące alokowania środków w różne rodzaje instrumentów finansowych. W tym celu w pierwszej kolejności, korzystając z narzędzi profilowania klienta, robodoradca poznaje jego cechy (określa poziom jego awersji do ryzyka, wiedzy finansowej, horyzontu inwestycyjnego itp.) oraz cele inwestycyjne. Następnie definiuje katalog możliwości inwestycyjnych (rodzaje instrumentów finansowych) i proponuje skład portfela uwzględniający założone cele i pożądany poziom ryzyka inwestycyjnego. Oprócz wstępnej rekomendacji można zaprojektować algorytmy do ciągłego monitorowania portfela i wykrywania odchyleń od docelowego profilu ryzyka inwestycyjnego. Po każdym ich zidentyfikowaniu klient otrzymuje powiadomienie o automatycznym przebudowaniu portfela i obniżeniu tego ryzyka. Przebudowa portfela inwestycyjnego może nastąpić również w związku z upływem czasem, kiedy zmieniają się cechy inwestora, tj. poziom awersji do ryzyka czy cele inwestycyjne. Niektóre roboty proponują też wdrożenie technik optymalizujących opodatkowanie dochodów z zysków kapitałowych bez wpływu na ekspozycję portfela na ryzyko: w tym celu rekomendują sprzedaż aktywów, które przynoszą stratę i wykorzystanie otrzymanych dzięki temu środków na zakup innych (potencjalnie zyskownych) aktywów o podobnym ryzyku. Ponadto robot może wyświetlać interesujące klienta statystyki, na przykład oczekiwaną roczną stopę zwrotu i zmienność oszacowane na podstawie przeszłych i przyszłych wyników otrzymanych na przykład z symulacji Monte Carlo (Bianchi i Briere, 2021).

Opisane etapy działania robodoradcy są typowe dla robodoradców określanych mianem 3.0 lub 4.0 (por. na przykład: Perez, 2019). Według Deloitte (2016) na poziomie 3.0 funkcjonuje około $80 \%$ robodoradców oferowanych inwestorom ze Stanów Zjednoczonych, z Wielkiej Brytanii, czy Unii Europejskiej i rozwija się ich możliwości w kierunku pełnej automatyzacji, czyli robodoradztwa 4.0. Beketov i in. (2018) twierdzą, że dopiero te poziomy odzwierciedlają „prawdziwe" robodoradztwo, ponieważ tak naprawdę dopiero na tych poziomach, wykorzystując metody ilościowe i algorytmy, roboty zarządzają portfelami inwestycyjnymi i dokonują ich optymalizacji. To powoduje, że wspomniana już wartość doradztwa finansowego jest w przypadku robotów realizowana przede wszystkim przez wyniki inwestycyjne, a mniej przez zaangażowanie oraz zaufanie. Można przyjąć jednak, że i te dwa ostatnie aspekty doradztwa finansowego są tu realizowane. Naturalnie w przypadku robotów w grę nie wchodzą zachowania ludzkie, jednak można uznać, że oba te elementy wartości doradcy są odzwierciedlone w poziomie zaawansowania i złożoności stosowanych przez roboty metod i algorytmów, są przecież tworzone przez programistów, którzy są ludźmi, a nie robotami. 


\subsection{Analiza SWOT doradcy $2.0 \mathrm{i}$ robodoradcy}

Od postępu technologicznego nie ma odwrotu. W związku z tym kanał tradycyjnego doradcy finansowego, tego sprzed doradcy 2.0 i robodoradcy, wydaje się pomału odchodzić do lamusa. Dziś na rynku w największym stopniu rozwijają się dwa ostatnie rodzaje doradztwa finansowego. Oba rozwiązania mają swoje zalety i wady, oba są też rozpatrywane w kategoriach szans i zagrożeń. W syntetyczny sposób analizę SWOT obu rozwiązań zaprezentowano poniżej i podsumowano w tabelach 8.1 i 8.2. Tam, gdzie to możliwe, starano się prezentować oba modele w kontekście drugiego rozwiązania.

\section{Doradca 2.0}

\section{Mocne strony}

Najważniejszą wartością tradycyjnego doradcy inwestycyjnego jest to, że jest on człowiekiem. Może on często i osobiście kontaktować się ze swoimi klientami i budować z nimi więź opartą na zaufaniu. Spotkania mogą się odbywać osobiście, ale również za pomocą różnych komunikatorów (na przykład Zoom czy MS Teams), do których przyzwyczaiła nas pandemia COVID-19. W trakcie rozmowy doradca otrzymuje od klientów szczegółowe informacje o nich samych, dzięki czemu jest w stanie lepiej zrozumieć ich preferencje, cele czy możliwości inwestycyjne i dostosować do nich w pełni strategię inwestycyjną. Na takich spotkaniach doradcy mogą nawet uczyć czy szkolić swoich klientów, a na pewno dzielić się z nimi wiedzą, dzięki czemu klienci stają się bardziej świadomi obecnego i przyszłego stanu swoich środków. Z takiej możliwości nie mają szansy skorzystać klienci robodoradców, których poziom wiedzy nie zmienia się dzięki współpracy z robotem; w czasie jej trwania mogą oni co najwyżej nabrać większego doświadczenia dotyczącego swoich inwestycji. Ważnym atutem doradcy 2.0 jest też to, że oferuje swoim klientom różne produkty inwestycyjne, a nie tylko podstawowe (na przykład fundusze ETF), które proponują robodoradcy.

\section{Słabe strony}

Mimo że wyposażony w narzędzia technologiczne zwiększające wydajność i efektywność, a przez to i obniżające koszt pracy, doradca 2.0 to jednak wciąż człowiek. $Z$ jednej strony, jak każdy człowiek, chce być za swoją pracę odpowiednio wynagradzany. W związku z tym nie może obsługiwać rzeszy drobnych inwestorów; musi się skupić na mniejszej liczbie bardziej majętnych osób, które są w stanie zapłacić więcej za jego usługi, przez co tworzy barierę wejścia dla mniej majętnych inwestorów. $Z$ drugiej strony, jak każdy człowiek, ulega różnym emocjom 
i zachowuje się nieracjonalnie. Badania naukowe nie dają jednoznacznej odpowiedzi, czy doradcy finansowi osiągają wyższe stopy zwrotu niż inwestorzy, którzy lokują środki na rynku finansowym samodzielnie. Poza tym nawet jeśli doradca finansowy jest wyposażony w narzędzia technologiczne, może je zignorować i doradzić klientowi coś zupełnie innego, powołując się na swoją wiedzę, doświadczenie czy intuicję. Klient, który ufa swojemu doradcy, nie zauważy nawet, że ten udziela porady subiektywnie. Błędne decyzje inwestycyjne pojedynczego klienta ostatecznie obciążają tylko jego samego (i ewentualnie doradcę finansowego, z którym może chcieć przestać współpracować), a nie cały system finansowy, jak to może być w przypadku robotów, które gdy dostaną błędny komunikat, nie zastanawiają się, nie reagują natychmiast na błędy, a wykonują zaprogramowany algorytm.

\section{Szanse}

Najważniejszą szansą rozwoju tradycyjnego doradztwa finansowego 2.0 jest połączenie pracy doradcy człowieka z doradcą robotem. W tej relacji na pierwszy plan zdecydowanie wysuwa się człowiek. Robot jest jego wsparciem, narzędziem, które człowiek wykorzystuje do oceny efektywności i optymalizacji budowanych portfeli i strategii inwestycyjnych. Dzięki temu jego praca jest bardziej wydajna i efektywna, a przez to mniej kosztowna. Tym samym może zostać zaoferowana większemu gronu inwestorów w różnych grupach wiekowych (w tym i millenialsom), co pokazuje potencjał rozwiązania hybrydowego. Potencjał ten dostrzegają nie tylko przedstawiciele największych instytucji finansowych na świecie, ale i największych niezależnych firm robodoradczych, które obecnie poważnie rozpatrują udział człowieka w procesie decyzyjnym klientów robodoradców.

\section{Zagrożenia}

Potencjał doradcy 2.0 może zostać zmarnowany, jeśli promocja korzyści związanych ze świadczeniem przez niego usług nie będzie odpowiednio przeprowadzona. Bez zrozumienia, jaką wartość tworzy doradca 2.0. i dlaczego należy rozpatrywać go jako realną alternatywę dla robodoradcy, potencjalni klienci, szczególnie osoby młode z pokolenia millenialsów, nie skorzystają z jego usług, a nawet nie będą próbować się z nim kontaktować. Przekonanie ich do doradcy 2.0 może się okazać zbyt trudne, szczególnie że pandemia COVID-19 zmusiła ich do izolacji społecznej, a jedyną bezpieczną formą kontaktu był (i po części wciąż jest) świat wirtualny, czyli świat robodoradców. Jeśli do tego jeszcze doradca 2.0 zostanie przy starych rozwiązaniach, w których obsłudze czuje się pewnie i bezpiecznie, a nie będzie na bieżąco wprowadzał nowinek technologicznych, które przyciągają młode osoby, może zostać przez nich odrzucony i ostatecznie również odejść do lamusa. 
Tabela 8.1. Analiza SWOT doradcy 2.0

\begin{tabular}{|c|c|}
\hline Mocne strony & Slabe strony \\
\hline $\begin{array}{l}\text { - systematyczny osobisty kontakt i budowanie } \\
\text { relacji opartej na zaufaniu między dwojgiem } \\
\text { ludzi - doradcą i inwestorem } \\
\text { - przejrzystość i szybkość przekazywania } \\
\text { informacji między doradcą i inwesto- } \\
\text { rem, również za pomocą komunikatorów } \\
\text { internetowych } \\
\text { - spersonalizowana oferta usług, wysoki sto- } \\
\text { pień dostosowania inwestycji do indywidu- } \\
\text { alnych (i aktualnych) potrzeb i ograniczeń } \\
\text { inwestora } \\
\text { - w związku z tym elastyczność w budowie } \\
\text { i zarządzaniu portfelem inwestycyjnym od- } \\
\text { zwierciedlająca w krótkim czasie zmieniają- } \\
\text { ce się potrzeby i cele inwestora } \\
\text { - brak negatywnego wpływu na stabilność } \\
\text { systemu finansowego przez pojedynczego } \\
\text { doradcę finansowego }\end{array}$ & $\begin{array}{l}\text { - wysokie koszty obsługi i zarządzania mająt- } \\
\text { kiem inwestorów ze względu na ich osobistą } \\
\text { obsługę } \\
\text { - wysokie bariery wejścia inwestora } \\
\text { ze względu na wyższy koszt doradztwa } \\
\text { oraz ze względu na wyższą minimalną } \\
\text { wpłatę środków do zarządzania } \\
\text { - potencjalne błędy psychologiczne i brak } \\
\text { gwarancji obiektywizmu mimo wsparcia } \\
\text { ze strony robota }\end{array}$ \\
\hline Szanse & Zagrożenia \\
\hline $\begin{array}{l}\text { - dzięki wykorzystaniu robotów w działalno- } \\
\text { ści trwały wzrost wydajności i efektywności } \\
\text { działania } \\
\text { - zmniejszenie kosztu działania i przez to } \\
\text { świadczenie usług szerszemu gronu inwesto- } \\
\text { rów z różnych grup wiekowych } \\
\text { - rozpatrywanie przez firmy robodoradcze } \\
\text { udziału człowieka w doradztwie finansowym }\end{array}$ & $\begin{array}{l}\text { - trudność w pozyskiwaniu nowych i młodych } \\
\text { klientów ze względu na preferowanie przez } \\
\text { nich robodoradców, szczególnie po okresie } \\
\text { izolacji spowodowanej pandemią COVID-19 } \\
\text { - przywiązanie do starszych procesów i plat- } \\
\text { form, które utrudniają wdrażanie nowych } \\
\text { prostych procesów usprawniających pracę } \\
\text { doradcy } 2.0\end{array}$ \\
\hline
\end{tabular}

Źródło: Opracowanie własne na podstawie: (Global (n.d.); Karabulut, 2012; Perez, 2019).

\section{Robodoradca}

\section{Mocne strony}

Wśród najważniejszych zalet robodoradztwa wymienia się koszty, które dla inwestorów są znacznie niższe niż koszty tradycyjnego doradztwa. Dzięki temu robodoradztwo przyciąga coraz większą liczbę osób indywidualnych, które bardzo często nigdy dotąd nie działały na rynku finansowym i dzięki temu powodują dynamiczny rozwój tej usługi na świecie. Ważną konsekwencją tego rozwoju jest wzrost konkurencji na rynku usług finansowych i presja na obniżanie kosztów przez tradycyjnych pośredników finansowych, co wraz z rozwojem wtórych rynków instrumentów finansowych przez zwiększenie aktywności handlowej na tych rynkach (a co za tym idzie i ich płynności, choć i ryzyka skali) ostatecznie pozytywnie wpływa na efektywność całego systemu finansowego (Perez, 2019). 
Ważną zaletą robodoradztwa jest szybkość obsługi - dzięki dostępnym online kwestionariuszom $\mathrm{w}$ formie ankiety wypełnianym przez inwestora $\mathrm{w}$ krótkim czasie następuje ocena akceptowanego przez niego ryzyka i na tej podstawie dobór instrumentów finansowych do portfela inwestycyjnego zbudowanego zgodnie z teorią portfela inwestycyjnego Markowitza (1952), a następnie jego monitoring. Dzięki aplikacji firmy robodoradczej inwestor może w łatwy i szybki sposób sprawdzić osiąganą stopę zwrotu lub zmienić poziom akceptowanego ryzyka, tym samym sygnalizując chęć dokonania zmian w tym portfelu. W zasadzie jest to jedyny przejaw emocjonalności działań wykonywanych w ramach robodoradztwa. W czasie turbulencji lub nagłych spadków na rynku finansowym robodoradca „chroni” inwestora przed napadami paniki i błędnymi decyzjami o natychmiastowej wyprzedaży instrumentów finansowych dzięki algorytmom, które są tak zaprogramowane, aby utrzymywać ustalony poziom ryzyka portfela. Jest to jeden z powodów osiągania przez robodoradców lepszych wyników inwestycyjnych niż w przypadku samodzielnych inwestycji lub w funduszach inwestycyjnych.

\section{Słabe strony}

Należy pamiętać, że pozyskanie nowych klientów robodoradców dużo kosztuje. Jones (2019) przytacza badania przeprowadzone przez pracowników brytyjskiego portalu finansowo-edukacyjnego Boring Money, które pokazują, że kosztuje to za dużo, bo nawet 400-500 GBP na osobę, co przy średniej wartości aktywów na klienta wynoszących 20000 GBP i około 50-100 punktów bazowych wynagrodzenia powoduje, że wiele firm robodoradczych wciąż przynosi straty. Na to, aby osiągały zyski, potrzeba około dziesięciu lat funkcjonowania (Jones, 2019). Wysoki koszt pozyskania klienta nie dziwi, szczególnie że potencjalni klienci muszą się pozbyć sceptycyzmu w stosunku do algorytmów umożliwiających podejmowanie decyzji inwestycyjnych oraz zaufać robodoradcy, który nie jest człowiekiem zatem nie może $\mathrm{z}$ nimi przedyskutować ich obaw związanych z podejmowaniem różnych inwestycji, określić, jakim poziomem ryzyka faktycznie się charakteryzują czy jakie instrumenty finansowe są dla nich odpowiednie. Poza tym w odróżnieniu od na przykład banków, ze względu na krótki czas działania na rynkach finansowych, firmy robodoradcze muszą zbudować swoją markę i zdobyć prestiż, a także dostosowywać się do regulacji prawnych, co również trwa i kosztuje (Perez, 2019).

\section{Szanse}

Rynek robodoradztwa ma ogromny potencjał głównie dzięki wszechobecnej digitalizacji, która w ostatniej dekadzie zadomowiła się nie tylko wśród osób indywidualnych, ale i wśród instytucji finansowych. Dziś nikt nie wyobraża sobie życia bez smartfonu, tabletu, notebooka czy innych urządzeń elektronicznych, 
na których są zainstalowane przyjazne dla użytkownika i wciąż ulepszane aplikacje instytucji finansowych. Usługi cyfrowe są wszechobecne, a sukcesywnie zwiększający się poziom digitalizacji społeczeństw powoduje, że rynek robodoradztwa ma szansę jeszcze bardziej dynamicznie się rozwijać.

Tradycyjne doradztwo finansowe to nie tylko budowanie i monitorowanie portfela inwestycyjnego, ale też oferowanie wielu znacznie bardziej skomplikowanych usług, które niełatwo wystandaryzować i zintegrować, na przykład w obszarze międzynarodowej optymalizacji podatkowej. Zdaniem Junga i in. (2019) standaryzacja i integracja bardziej zaawansowanych usług jest kluczowym czynnikiem przyciągnięcia do robodoradztwa większej liczby inwestorów, którzy obecnie polegają na umiejętnościach tradycyjnych doradców finansowych. Doradcy ci skupiają się dziś już nie na analizie portfela inwestycyjnego zgodnie z teorią Markowitza (1952), ale na realizowaniu długoterminowego planu inwestycyjnego zorientowanego na cele i uwzględniającego różnorodne indywidualne preferencje inwestycyjne, horyzonty czasowe i profile ryzyka danego klienta. Taki plan wymaga zbudowania znacznie bardziej zindywidualizowanego modelu, który optymalnie dostosowuje się do potrzeb danego klienta (Jung i in., 2019). Sironi (2016) zauważa, że wykorzystując osiągnięcia nowoczesnej technologii, w tym analizę big data, robodoradcy mogą oceniać, jakimi cechami charakteryzują się ich klienci w czasie, kiedy są na studiach, kiedy kupują pierwszą nieruchomość bądź kiedy przechodzą na emeryturę. Na tej podstawie robodoradcy będą w stanie realizować długoterminową strategię inwestycyjną, Zaawansowana personalizacja tej strategii jest jednym z najważniejszych elementów rozwoju tego rynku w przyszłości.

Statista.com przewiduje, że aktywa zarządzane przez robodoradców osiągną w 2021 roku wartość 1426993 mln USD oraz 4873 USD na jednego klienta. Wartość aktywów w latach 2021-2025 ma przynieść roczną stopę wzrostu (CAGR 2021-2025) na poziomie $18,83 \%$, co daje do 2025 roku przewidywaną całkowita kwotę tego rynku w wysokości $2845488 \mathrm{~m} \ln$ USD podzieloną na 478 886,0 tys. klientów. Liczby te pokazują, że rozwój tego rynku jest bardzo dynamiczny, jednak to wciąż około $1,6 \%$ rynku zarządzania majątkiem. Jak dotąd robodoradcy nie zainteresowali zatem swoimi usługami zbyt dużej liczby osób nazywanych high net worth individuals (HNWI). Prawdopodobnym rozwiązaniem tego problemu jest połączenie usług robodoradcy z pracą tradycyjnego doradcy inwestycyjnego, czyli rozwiązanie hybrydowe dyskutowane wyżej. Sironi (2016) nazywa tę transformację z robodoradców B2B na robo-4-doradców B2B2C i jako przykład takiego rozwiązania podaje wspomnianą już firmę robodoradczą Betterment, która swoim klientom oferuje kontakt z doradcą człowiekiem oraz oferowaną przez nią platformę „Betterment 4 Advisors" dostarczającą tradycyjnym doradcom finansowym 2.0 narzędzi robodoradztwa. Ponadto firmy robodoradcze angażują się w budowanie modeli biznesowych $\mathrm{B} 2 \mathrm{~B}$, w ramach których dostarczają usługi w chmurze tym firmom, które chcą mieć robodoradztwo w swojej ofercie, ale nie mają do tego zasobów. 


\section{Zagrożenia}

Wśród zagrożeń w branży robodoradztwa wymienia się już wspomnianą wysoką konkurencję czy niepewność co do strony regulacyjnej tego rynku. Istotny jest też brak akceptacji przez użytkowników lub występujące z ich strony ryzyko operacyjne. Największą grupą klientów robodoradców są wciąż osoby młode, mało majętne i niemające doświadczenia $\mathrm{w}$ funkcjonowaniu na rynku finansowym. Wybierając tę formę doradztwa, mogą podpisać umowę o współpracę, której do końca nie rozumieją i która jest sprzeczna z ich wolą. Dodatkowo nie znajdą po drugiej stronie odpowiedzi na ewentualne wątpliwości. Może to naruszać ich prawa i interesy (Liu, 2020). Ryzyko operacyjne występuje też po stronie firm robodoradczych. Firmy muszą ustanowić odpowiednie mechanizmy kontrolne wokół swoich zautomatyzowanych środowisk doradców, aby złagodzić ryzyko związane z segmentacją klientów, planowaniem ciągłości działania i zarządzaniem IT. Ważne jest również, aby uchronić algorytm przed zmianami lub manipulacjami, które mogą wpływać na doradztwo inwestycyjne lub spowodować, że algorytm wskaże kroki niezgodne z najlepszym interesem klientów (Deloitte, 2021). Wiąże się to z największym zagrożeniem dla rozwoju tej branży, a jednocześnie dla całego systemu finansowego, czyli z sytuacją stadnego zachowania robodoradców o podobnych strategiach w momencie załamania na rynkach finansowych. Może ono spowodować nagłe i niemożliwe do zatrzymania w krótkim czasie negatywne zmiany w portfelach inwestycyjnych klientów wywołane działaniem algorytmów, które są automatami realizującymi transakcje kupna lub sprzedaży, nieumiejącymi ocenić nienormalnej sytuacji. Flash-crashes, bo tak nazywają się takie sytuacje, pojawiły się już w przeszłości. Przykładowo 23 kwietnia 2013 roku o godz.13:07 załamała się wycena Dow Jones Industrial Average ${ }^{5}$ po ataku syryjskich hakerów na twitter Associate Press. Hakerzy wprowadzili tam informację o wybuchu w Białym Domu i odniesieniu w związku z tym obrażeń przez ówczesnego prezydenta Stanów Zjednoczonych Baracka Obamy. Łącznie w ciągu trzech minut do czasu sprostowania przez AP, że był to atak hakerski, wycena akcji na New York Stock Exchange spadła o 136 mld USD. W ciągu następnych trzech minut wycena DJIA wróciła do stanu sprzed tego ataku, ale algorytmy modeli transakcyjnych funduszy hedge zajmujących się handlem o wysokiej częstotliwości (high frequency trading, HFT) zareagowały na spadek DJIA natychmiast, powodując zawarcie nieodwracalnych transakcji, które spowodowały straty na portfelach tych funduszy. Można sobie wyobrazić, że podobna sytuacja może wystąpić w ,czarnym” dniu paniki na rynkach akcji z powodów ekonomicznych, które rozpoczynają czas kryzysu finansowego. Takim dniem był choćby 15 września 2008 roku, czyli dzień ogłoszenia bankructwa Lehman Brothers, który stał się symbolem globalnego kryzysu finansowegoz lat 2007-2009 (Perez, 2019).

\footnotetext{
${ }^{5}$ Dow Jones Industrial Average spadł wtedy w ciągu trzech minut o 143 pb.
} 
Tabela 8.2. Analiza SWOT robodoradcy

\begin{tabular}{|c|c|}
\hline Mocne strony & Słabe strony \\
\hline $\begin{array}{l}\text { - niskie bariery wejścia inwestora ze względu } \\
\text { na niższy koszt robodoradztwa niż w przy- } \\
\text { padku doradztwa tradycyjnego } \\
\text { - możliwość pozyskania przez robodorad- } \\
\text { cę szerokiego grona inwestorów o różnej } \\
\text { wartości aktywów i rożnych potrzebach } \\
\text { inwestycyjnych } \\
\text { - szybkość obsługi inwestora (krótki czas od } \\
\text { oceny ryzyka do zmian w portfelu inwesty- } \\
\text { cyjnym przywracających stan równowagi) } \\
\text { - łatwy i szybki dostęp dla inwestora do róż- } \\
\text { nych informacji, w tym informacji finanso- } \\
\text { wych i na temat wyników inwestycyjnych } \\
\text { - podejmowane przez inwestora decyzje inwe- } \\
\text { stycyjne są obiektywne, nie emocjonalne } \\
\text { - lepsze wyniki inwestycyjne niż w przypadku } \\
\text { samodzielnie zarządzanych portfeli lub fun- } \\
\text { duszy inwestycyjnych } \\
\text { - wzrost stabilności systemu finansowego: } \\
\text { - wzrost efektywności systemu finansowego } \\
\text { przez wzrost konkurencji na rynku usług } \\
\text { finansowych i presja na obniżanie opłat za } \\
\text { doradztwo i zarządzanie aktywami przez } \\
\text { tradycyjne instytucje finansowe } \\
\text { - rozwój wtórnych rynków instrumentów } \\
\text { finansowych przez zwiększenie aktywno- } \\
\text { ści handlowej na tych rynkach } \\
\text { - możliwa synergia wiedzy i innowacji mię- } \\
\text { dzy tradycyjnymi instytucjami finansowy- } \\
\text { mi a firmami robodoradczymi } \\
\text { - potencjał zwiększenia dostępu wielu osób } \\
\text { indywidualnych do rynków finansowych, } \\
\text { a także dostępu rynków finansowych do } \\
\text { oszczędności tych osób }\end{array}$ & $\begin{array}{l}\text { - wysoki koszt pozyskania klienta przez robo- } \\
\text { doradcę oraz niska opłacalność biznesu na- } \\
\text { wet przy dużej liczbie drobnych inwestorów } \\
\text { - brak interakcji i relacji inwestora z doradcą } \\
\text { finansowym - człowiekiem } \\
\text { - wynikający z powyższego brak elastycz- } \\
\text { ności w budowie i zarządzaniu portfelem } \\
\text { inwestycyjnym } \\
\text { - oraz brak dostosowania inwestycji do indy- } \\
\text { widualnych potrzeb i ograniczeń inwestora } \\
\text { (na przykład co do ryzyka inwestycyjnego), } \\
\text { które mogą być niewystarczająco dokładnie } \\
\text { ocenione } \\
\text { - ogólny brak przejrzystości sposobów wy- } \\
\text { korzystania informacji pozyskanych od } \\
\text { inwestorów } \\
\text { - możliwy ukryty konflikt interesów prowa- } \\
\text { dzący do wzrostu ukrytych kosztów dla } \\
\text { inwestora } \\
\text { rosnące koszty dostosowania do regulacji } \\
\text { prawnych (na przykład MiFID II itp.) } \\
\text { - ryzyko skali związane ze zwiększaniem ak- } \\
\text { tywności handlowej na rynkach finansowych }\end{array}$ \\
\hline Szanse & Zagrożenia \\
\hline $\begin{array}{l}\text { - wszechobecność usług cyfrowych } \\
\text { - możliwość standaryzacji i integracji usług } \\
\text { doradztwa finansowego } \\
\text { - inwestowanie zorientowane na cele } \\
\text { - uzupełnienie robodoradców o kontakt z do- } \\
\text { radcą człowiekiem oraz uzupełnienie pracy } \\
\text { tradycyjnych doradców finansowych } 2.0 \\
\text { o usługi robodoradztwa }\end{array}$ & $\begin{array}{l}\text { - branża o wysokiej konkurencji } \\
\text { - możliwe zagrożenia ze stron instytucji regu- } \\
\text { lujących rynki finansowe } \\
\text { - brak akceptacji przez użytkowników i ryzy- } \\
\text { ko operacyjne po stronie klientów } \\
\text { - ryzyko operacyjne po stronie robodoradcy } \\
\text { - istotne zagrożenie dla stabilności systemu } \\
\text { finansowego w sytuacji spadków cen na } \\
\text { giełdach i kryzysów finansowych }\end{array}$ \\
\hline
\end{tabular}

Źródło: (Jung i in., 2019; Perez, 2019). 


\subsection{Podsumowanie}

Lista błędów psychologicznych popełnianych przez inwestorów indywidualnych jest tak długa, że dziś mało kto podważa sens doradztwa finansowego. Przez ostatnie 70 lat biznes ten ewaluował od maklerów papierów wartościowych obsługujących najbogatsze osoby indywidualne, przez konsultantów i doradców finansowych obsługujących również osoby mniej bogate i majętne aż do doradztwa hybrydowego lub samodzielnych robotów wyposażonych w narzędzia cyfrowe do badania i oceny efektywności portfela inwestycyjnego, które świadczą usługi doradztwa finansowego każdemu, nawet najdrobniejszemu inwestorowi detalicznemu.

Według Statista.com w obliczu słabszych wyników inwestycyjnych różnego rodzaju form inwestycji, w tym ETF, robodoradztwo szybko zyskuje zainteresowanie opinii publicznej. Duże fundusze inwestycyjne wdrażają technologię robo-advisory, ponieważ w porównaniu ze staromodnymi alternatywnymi rozwiązaniami zautomatyzowane zarządzanie portfelem zapewnia wysokie stopy zwrotu. Należy się również spodziewać konsolidacji pomiędzy niezależnymi graczami w branży ze względu na to, że rentowność jest silnie powiązana ze skalowalnością i dużą wartością zarządzanych aktywów. Choć robodoradztwo sprawdziło się w ostatnich latach i pojawiło się w ofercie wielu instytucji finansowych, to jeszcze nie udowodniło swojej skuteczności w kolejnej recesji.

W raporcie EY z 2021 roku czytamy, że wiara w wartość narzędzi cyfrowych nie oznacza, że wszyscy klienci chcą relacji czysto wirtualnych. Klienci dzielą się na preferujących zaangażowanie tradycyjnych doradców finansowych (35\%), zwolenników modelu opartego na technologii cyfrowej (28\%) oraz na szukających rozwiązania hybrydowego (37\%). Na pierwszy rzut oka grupy te rozkładają się równomiernie. Jednak zainteresowanie nowymi technologiami ze strony klientów zamożnych i bardzo zamożnych z wyżu demograficznego jest nieporównywalnie większe niż zainteresowanie millenialsów doradztwem typowo tradycyjnym. Poza tym co czwarty inwestor o wysokiej wartości aktywów netto i co piąty klient o bardzo wysokiej wartości aktywów netto wskazuje narzędzia cyfrowe jako swój pierwszy wybór (EY Global, 2021). To dowodzi bardzo wysokiego potencjału robodoradztwa, nie wyklucza jednak rozwoju usług doradcy 2.0.

W podsumowaniu należy powrócić do pytania zadanego na początku rozdziału, czy człowiek ma szansę dominować nad robotem w doradztwie finansowym. Według specjalistów EY instytucje finansowe rozwijają swoje kanały zgodnie z preferencjami inwestorów, które będą współistnieć w dającej się przewidzieć przyszłości. Moim zdaniem koegzystencja doradcy 2.0 i robodoradcy jest jak najbardziej możliwa i pożądana, nawet w długiej perspektywie. Jednak człowiek w większym stopniu będzie korzystał z robotyki, a robot - dzięki osiągnięciom sztucznej inteligencji - zostanie ,uczłowieczony”. Wyobrażam sobie, że doradca finansowy może w przyszłości przybierać dwie postaci. Pierwsza to doradca 
człowiek (może nazwany doradcą 3.0?), gdzie rola doradcy będzie wciąż dominująca, ale głównie po to, by nawiązać i utrzymać dobrą relację z klientem, który będzie tego oczekiwał, i by reagować na sytuacje kryzysowe, nieprzewidywalne, kiedy robot zachowa się wbrew pozorom nieracjonalnie, jak w przypadku flash-crashes. Druga to robodoradca, który jednak nie będzie tylko automatem, ale będzie posiadał cechy człowieka; będzie to robot działający w wirtualnym świecie, ale na tyle wyszkolony, aby dać klientowi odczuć, że buduje z nim relację opartą na jego potrzebach i uwzględniającą jego emocje. Sądzę, że takie dwutorowe podejście w doradztwie finansowym jest nieuniknione ze względu na jego koszt. W przypadku osób majętnych lub bogatych obsługą klienta będzie się zajmował człowiek, któremu się za to zapłaci. W przypadku osób detalicznych takim doradcą będzie robot, jednak ,nauczony” być miłym, odpowiadać na różne pytania czy reagować na różne nastroje klientów. Nasuwa się pytanie, kiedy to nastąpi. Uważam, że już wkrótce. $Z$ jednej strony ze względu na stronę podażową doradztwa finansowego chętną do pokonania konkurencji i zajęcia jak największej części tego rynku. $Z$ drugiej strony ze względu na stronę popytową, która jest skłonna zapłacić niewielką część swoich środków za profesjonalną poradę, aby efektywnie ulokować nawet najmniejsze oszczędności mogące się przyczynić do poprawy ich dobrobytu przed i po tym, jak przejdą na emeryturę.

\section{Bibliografia}

Bach, L., Calvet, L. E. i Sodini, P. (2020). Rich pickings? Risk, return, and skill in household wealth. American Economic Review, 110(9), 2703-2747. https://doi.org/10.1257/ aer.20170666

Beketov, M., Lehmann, K. i Wittke, M. (2018). Robo advisors: quantitative methods inside the robots. Journal of Asset Management, 19(6), 363-370. https://doi.org/10.1057/ s41260-018-0092-9

Beshears, J., Choi, J. J., Laibson, D. i Madrian, B. C. (2018). Behavioral household finance. https://doi.org/10.1016/bs.hesbe.2018.07.004

Bianchi, M. (2018). Financial literacy and portfolio dynamics. Journal of Finance, 73(2), 831-859. https://doi.org/10.1111/jofi.12605

Bianchi, M. i Briere, M. (2021). Robo-advising: Less AI and more XAI?. SSRN Electronic Journal. https://doi.org/10.2139/ssrn.3825110

Campbell, J. Y. (2006). Household finance. Journal of Finance, 61(4), 1553-1604. https:// doi.org/10.1111/j.1540-6261.2006.00883.X

Campbell, J. Y., Jackson, H. E., Madrian, B. C. i Tufano, P. (2011). Consumer financial protection. Journal of Economic Perspectives, 25(1), 91-114. https://doi.org/10.1257/ jep.25.1.91

Chiu, I. (2016). Fintech and disruptive business models in financial products, intermediation and markets - policy implications for financial regulators. Journal of Technology 
Law and Policy, 21 (1), 55-112. Pobrane z http://www.journaloftechlaw.org/volume-21--issue-1.html

Cruciani, C. (2017). Understanding investor behaviour. W: Investor decision-making and the role of the financial advisor (s. 3-36). Springer International Publishing. https:// doi.org/10.1007/978-3-319-68234-1_1

D’Acunto, F. i Rossi, A. G. (2020). Robo-advising. SSRN Electronic Journal. https://doi. org/10.2139/ssrn.3545554

Deloitte. (2016). The expansion of Robo-Advisory in wealth management . Pobrane z https://www2.deloitte.com/de/de/pages/financial-services/articles/the-expansionof-robo-advisory-in-wealth-management.html

Deloitte. (2021). Robo-advising platforms carry new risks. Pobrane z https://www2. deloitte.com/us/en/pages/risk/articles/robo-adviser-platform-risks-asset-wealthmanagement-firms.html

EY Global. (n.d.). The evolution of Robo-advisors and Advisor 2.0 model. Pobrane 19 września 2019 z https://www.pdffiller.com/474690452--EY-The-evolution-of-Roboadvisors-and-Advisor-20-model-

EY Global. (2021). 2021 EY Global wealth research report. Pobrane z https://www.ey.com/ en_gl/wealth-management-research

Fagereng, A., Guiso, L., Malacrino, D. i Pistaferri, L. (2020). Heterogeneity and persistence in returns to wealth. Econometrica, 88(1), 115-170. https://doi.org/10.3982/ecta14835

Foerster, S., Linnainmaa, J. T., Melzer, B. T. i Previtero, A. (2017). Retail financial advice: does one size fit all?. Journal of Finance, 72(4), 1441-1482. https://doi.org/10.1111/ jofi. 12514

Gennaioli, N., Shleifer, A. i Vishny, R. (2015). Money doctors. Journal of Finance, 70(1), 91-114. https://doi.org/10.1111/jofi.12188

Hackethal, A., Haliassos, M. i Jappelli, T. (2012). Financial advisors: A case of babysitters?. Journal of Banking and Finance, 36(2), 509-524. https://doi.org/10.1016/j. jbankfin.2011.08.008

Inderst, R. i Ottaviani, M. (2012). Financial advice. Journal of Economic Literature, 50(2), 494-512. https://doi.org/10.1257/jel.50.2.494

Jones, A. (2019). Why robo-advisors are struggling to break even. International Banker. Pobrane $\mathrm{z}$ https://internationalbanker.com/brokerage/why-robo-advisors-are-struggling-to-break-even/

Jung, D., Dorner, V., Glaser, F. i Morana, S. (2018). Robo-advisory: digitalization and automation of financial advisory. Business and Information Systems Engineering, 60(1), 81-86. https://doi.org/10.1007/s12599-018-0521-9

Jung, D., Dorner, V., Weinhardt, C. i Pusmaz, H. (2018). Designing a robo-advisor for risk-averse, low-budget consumers. Electronic Markets, 28(3), 367-380. https://doi. org/10.1007/s12525-017-0279-9

Jung, D., Glaser, F. i Köpplin, W. (2019). Robo-advisory: Opportunities and risks for the future of financial advisory. W: Contributions to management science (s. 405-427). Springer. https://doi.org/10.1007/978-3-319-95999-3_20

Karabulut, Y. (2012). Financial advice: An improvement for worse?. SSRN Electronic Journal. https://doi.org/10.2139/ssrn.1710634 
Kolakowski, M. (2019). The history and role of a financial consultant. Pobrane $\mathrm{z}$ https:// www.thebalancecareers.com/financial-consultant-1286728

Kunz, K. i Martin, J. (2015). Into the breech: The increasing gap between algorithmic trading and securities regulation. Journal of Financial Services Research, 47(1), 135-152. https://doi.org/10.1007/s10693-013-0184-0

Library of Congress. (n.d.). Stock Exchanges - Wall Street and the stock exchanges: historical resources. Research guides. Pobrane 7 lipca 2021 z https://guides.loc.gov/ wall-street-history/exchanges

Linnainmaa, J. T., Melzer, B. T. i Previtero, A. (2021). The misguided beliefs of financial advisors. Journal of Finance, 76(2), 587-621. https://doi.org/10.1111/jofi.12995

Liu, R. (2020). Research on financial risks of robo-advisor platforms. E3S Web of Conferences, 218, 01035. https://doi.org/10.1051/e3sconf/202021801035

Lusardi, A., Michaud, P. C. i Mitchell, O. S. (2017). Optimal financial knowledge and wealth inequality. Journal of Political Economy, 125(2), 431-477. https://doi. org/10.1086/690950

Lusardi, A. i Mitchell, O. S. (2014). The economic importance of financial literacy: Theory and evidence. Journal of Economic Literature, 52(1), 5-44. https://doi.org/10.1257/ jel.52.1.5

Markowitz, H. (1952). Portfolio selection. The Journal of Finance, 7(1), 77-91. https:// doi.org/10.2307/2975974

Perez, K. (2019). Robo-doradztwo - alternatywa czy uzupełnienie tradycyjnego doradztwa inwestycyjnego?. W: W. Przybylska-Kapuścińska i K. Perez (red.), Polityka pieniężna i rynki finansowe wobez wyzwań gospodarki 4.0 (s. 171-191). CeDeWu.

Schwinn, R. i Teo, E. G. S. (2018). Inclusion or exclusion? Trends in robo-advisory for financial investment services. W: Handbook of blockchain, digital finance, and inclusion (Vol. 2, s. 481-492). Elsevier Inc. https://doi.org/10.1016/B978-0-12-8122822.00021-8

Sironi, P. (2016). FinTech innovation: From robo-advisors to goal based investing and gamification. Wiley. Pobrane z https://www.wiley.com/en-us/FinTech+Innovation\%3A+Fro $\mathrm{m}+$ Robo+Advisors+to+Goal+Based+Investing+and+Gamification-p-9781119226987 